\author{
Tsaqofiya : Jurnal Pendidikan Bahasa dan Sastra Arab \\ Vol. 2 No. 1 Januari 2020, hlm. 1-19 \\ P-ISSN : 2685-7022, E-ISSN : 2685-7103 \\ DOI : $10.21154 /$ tsaqofiya.v2i1.42
}

\title{
KONSTRUKSI SINTAKSIS KAIFIATUL IKHBAR DALAM AKAD IJAB KABUL PERNIKAHAN
}

\author{
Samsul Arifin', Miftakhul Ma'arif' ${ }^{2}$ Muhammad Muchlish Huda ${ }^{3}$ \\ ${ }^{1}$ Mahasiswa IAIN Ponorogo, ${ }^{2}$ Mahasiswa IAIN Ponorogo, ${ }^{3}$ Dosen IAIN Ponorogo \\ 1Thezamboys775@gmail.com,2miftahul.maarif10@gmail.com, \\ 3muhammadmuchlishhuda@gmail.com
}

\section{Abstract}

In the context of composing Arabic sentences, the rules of kaifiatul ikhbar are included in the rules which are basic and foundation. The kaifiatul ikhbar rules are formed from the composition of the mubtada and khobar and are used in various forms of sentences, including the sentence structure of the marriage consent. Accuracy in pronouncing the kabul marriage license sentence including the arrangement of the preacher and khobar becomes important considering this kabul consent will be a legal requirement or cancellation of a marriage contract. This study attempts to analyze and present several forms of kabul mariage agreement and syntactic analysis, especially in the kaida of kaifiatul ikhbar. By using a library approach and linguistic analysis from its syntactic aspects, the results of this study indicate that there are 11 forms of kaifiyatul ikhbar with various syntactic analysis specifications. This shows that the form of kaifiatul ikhbar in the marriage contract is actually not only one forms, but with a variety of sentence forms.

Keyword: Syntactic, Arabic Language, Kaifiatul Ikhbar, Ijab Kabul

\section{Abstrak}

Dalam konteks penyusun kalimat berbahasa Arab, kaidah kaifiatul ikhbar termasuk pada kaidah yang bersifat dasar dan pondasi. Kaidah kaifiatul ikhbar ini terbentuk dari susunan mubtada dan khobar dan digunakan dalam berbagai bentuk kalimat, termasuk dalam susunan kalimat ijab Kabul pernikahan. Ketepatan pengucapan kalimat ijab Kabul pernikahan termasuk di dalamnya susunan mubtada dan khobarnya menjadi penting mengingat ijab Kabul ini akan menjadi syarat sah atau batalnya sebuah akad pernikahan. Penelitian ini berupaya menganalisis dan menyajikan beberapa bentuk akad ijab Kabul pernikaha serta analisisnya secara sintaksis terutama pada bagian kaifiatul ikhbar-nya. Dengan menggunakan pendekatan kepustakaan dan analisis kebahasaan dari aspek sintaksisnya, hasil penelitian ini menunjukkan bahwa terdapat 11 bentuk kaifiyatul ikhbar dengan spesifikasi analisis sintaksisnya yang beragam. Hal tersebut menunjukkan bahwa bentuk kaifiatul ikhbar dalam akad pernikahan sebenarnya tidak hanya tunggal, akan tetapi dengan bentuk kalimat yang beragam.

Kata Kunci: Sintaksis, Bahasa Arab, Kaifiatul Ikhbar, Ijab Kabul 


\section{PENDAHULUAN}

Dalam konteks penyusun kalimat berbahasa Arab, kaidah kaifiatul ikhbar termasuk pada kaidah yang bersifat dasar dan pondasi utamanya dalam diskursus ilmu bahasa Arab yang berbeda dengan bahasa lain termasuk bahasa Indonesia ${ }^{1}$ dan perlu dipelajari oleh pelajar yang intens dalam bahasa Arab terutama di ma'had. ${ }^{2}$ Kaidah kaifiatul ikhbar ini terbentuk dari susunan mubtada dan khobar dan digunakan dalam berbagai bentuk kalimat, termasuk dalam susunan kalimat ijab Kabul pernikahan. Ketepatan pengucapan kalimat ijab Kabul pernikahan termasuk di dalamnya susunan mubtada dan khobarnya menjadi penting mengingat ijab Kabul ini akan menjadi syarat sah atau batalnya sebuah akad pernikahan.

Dalam ilmu nahwu, Kaifiyatul ikhbar merupakan tata cara untuk membuat macam-macam bentuk khobar, ataupun cara merubah pola kalimat menjadi beberapa bentuk, namun tetap dalam satu makna. Dalam pembahasan ini terdapat dua unsur penting yang dapat membentuk suatu kalimat bisa sempurna, ${ }^{3}$ yaitu mubtada' dan khobar. Dua unsur tersebut tidak bisa lepas dari pembahasan mubtada dan khobar.

Secara bahasa mubtada' berarti memulai, sehingga dalam istilah ilmu nahwu, mubtada merupakan isim yang berada di awal kalimat, walaupun terkadang yang menjadi mubtada' ini bukan isim sarih namun terkadang berupa al-masdar almu'awwal. Hukum isim yang dimulai pada awal kalimat tersebut adalah Marfu' (dibaca akhir katanya dengan harakah dhamma), kecuali apabila isim tersebut didahului oleh harf jar tambahan atau yang menyerupainya maka hukumnya secara Lafadz adalah majrur namun kedudukannya dalam kalimat tetaplah marfu'4 Sementara khabar adalah isim atau kata benda yang dibaca rofa' yang secara hukum kalimat disandarkan pada mubtada' ${ }^{5}$

Pertanyaannya, dalam konteks akad pernikahan atau dikenal masyarakat sebagai akad ijab Kabul sebenarnya bagaimanakah posisi kalimat tersebut terutama dalam

\footnotetext{
1 Hasyim Asy'ari, Nadzariyatu Nasy'ati al-Lughoh wa tafri'uha fi at-Thurab al-Arabiy, (atTadris: al-Mujallad as-Saniy, 2017), 96

2 Jamaluddin Shiddiq, "Model Pembelajaran Bahasa Arab Di Ma'had Al-Jami'ah Walisongo Semarang," Lisania: Journal of Arabic Education and Literature 2, no. 2 (2018): 102-20.

3 Muhammad Muchlish Huda, al-Baidagogiyatu an-naqdiyyatu: al-Ittijah al-jadid fi ta'lim allughah al-arabiyah li ghair an-nathiqina biha, Abjadia International Journal of Education, Vol 3 No. 1, 2018.

4. Djawahir Djuha, Tata Bahasa Arab (Ilmu Nahwu), Tarjamah Matan Jurumiyah. (Bandung: Sinar Baru Algesindo, 1995), 85.

${ }^{5}$ Ibid, 87
} 
konteks kaidah sintaksis mubtada' dan khobarnya. Lalu apakah akad ijab Kabul sebenarna hanya berbentuk satu akad saja, ataukah boleh menggunakan bentuk akad ijab Kabul yang lain yang memenuhi unsur kaifiatul ikhbar. Signifikansi artikel ilmiah ini adalah terletak pada pertanyaa bagaimanakah analisis sintaksis dari akad ijab Kabul dengan menggunakan bentuk kaidah kaifiatul ikhbar yang lain tersebut serta bagaimana bentuk kaidah dan cara penyusunannya.

\section{METODE}

Metode yang digunakan dalam penelitian ini adalah metode kajian pustaka dengan analisa sintaksis kalimat berbahasa Arab. Kajian pustaka merupakan analisis terhadap data objek material penelitian dengan berbasis pada objek formal penelitian yang berupa referensi seperti buku, jurnal atau paper, artikel, disertasi, tesis, skripsi, hand outs, laboratory manuals, dan karya ilmiah lainnya yang dikutip di dalam penulisan proposal. Semua referensi yang tertulis dalam kajian pustaka harus dirujuk di dalamnya. ${ }^{6}$

Penelitian ini berupaya menganalisis dan menyajikan beberapa bentuk akad ijab Kabul pernikaha serta analisisnya secara sintaksis terutama pada bagian kaifiatul ikhbar-nya. Dengan menggunakan pendekatan kepustakaan dan analisis kebahasaan dari aspek sintaksisnya. Dengan menggunakan metode analisa sintaksis, objek material dalam artikel ini adalah beberapa kaidah ijab Kabul yang terdapat dalam pernikahan. Adapun objek formal nya adalah teori sintaksi kaifiyatul ikhbar dan seputar mubtada dan khobar serta cakupan pembahasan mengenainya. Dokumen, semua riset melibatkan penggunaan dan analisis dokumen. ${ }^{7}$

Adapun bentuk analisis penelitian ini mendasarkan pada dokumen dan buku serta pandangan penulis lain. Semua riset melibatkan penggunaan dan analisis dokumen tersebut melalui membaca, menganalisa dan mengkritisi tulisan-tulisan yang berkaitan dengan objek material dan objek formal penelitian. ${ }^{8}$

\section{Hasil Penelitian}

6 http://fatkhan.web.id/pengertian-dan-definisi-kajian-pustaka/ (diakses 12 Mei 2020, pukul 22.09 WIB)

7 S. Nasution, Metode Penelitian Naturalistik Kualitatif, (Bandung: Tarsito, 1988), 9-12.

8. Loraine Blaxter, Christina Hughes, Malcolm Thight, How To Research, (England: Open University Press, 2001) hal 252. Lihat juga: Robert K. Yin, Studi Kasus: Desain dan Metode, alih bahasa M. Djauzi Mudzakir (Jakarta: Rajawali Pers, 2009), hal. 18. 


\section{1) Mubtada' Dan Ruang Lingkup Pembagiannya}

Mubtada' adalah satu dari dua unsure pembentuk Jumlah Ismiyyah (Kalimat yang terdiri dari susunan kata benda). Unsur jumlah ismiyah sendiri ada dua, yaitu mubtada' (pemula kalimat) dan khabar (Penjelasnya). Mubtada' adalah isim (selanjutnya disebut kata benda) yang berada di awal kalimat yang berposisi sebagai subyek dalam kalimat (jumlah). Sedangkan khabar adalah kata benda yang berposisi sebagai keterangan sehingga sebuah kalimat dalam bahasa Arab menjadi sempurna. ${ }^{9}$. Khobar dalam kalimat berbahasa Arab berkedudukan sebagai predikat dalam sebuah kalimat.

Mubtada' terbagi menjadi dua bagian, yaitu mubtada' yang zhahir dan mubtada' yang mudhmar (dhamir). ${ }^{10}$ Mubtada' terbagi menjadi dua yaitu Mubtada' Isim Zhahir dan Mubtada' isim dlomir. ${ }^{11}$

Dalam konteks pembahasan bahasa Arab, terdapat dua macam Jumlah (Kalimat) yakni jumlah Ismiyah dan Jumlah Fi'liyah. Jumlah Ismiyah terdiri dari Mubtada' dan Khobar. Banyak Ahli bahasa Arab memberikan definisi mengenai Mubtada'. Beberapa diantaranya seperti berikut. Yang pertama definisi Mubtada' yang diungkapkan oleh Abu Hazim Mubarok. Menurutnya, Mubtada' adalah isim marfu' yang kosong atau bebas dari 'amil lafazh, yakni : yang merofa'kan mubtada' itu bukan 'amil lafazh, seperti fa'il atau naibul fa'il, melainkan oleh 'amil maknawi, yaitu oleh ibtida' atau permulaan kalimat saja. ${ }^{12}$

Isim yang dapat berposisi sebagai mubtada' pada umumnya adalah isim-isim ma'rifah, dan sebahagian kecil ada yang terdiri dari isim nakirah. ${ }^{13}$ Pengertian Mubtada' juga diungkapkan dalam kitab Imriti yaitu kalimat isim yang dibaca rofa' yang disepikan dari amil-amil lafdziyah. ${ }^{14}$ Yang merofa'kan mubtada' adalah 'amil maknawi ibtida', yaitu sepinya mubtada' dari 'amil-'amil lafdzi yang berupa كان dan sejenisnya, إنّ dan sejenisnya. Menurut mazhab Imam Sibawaih dan sebagian besar ulama Bashrah, bahwa mubtada' itu di-marfu-

\footnotetext{
${ }^{9}$ Fuad Ni'mah, Mulakhkhash Qawaid al - Lughah al - Arabiyah, (Bairut: Dar al-Tsaqafah alIslamiyah, tt), 30

10 Ibid, 286

11 Muhammad bin Muhammad, Al-Jurumiyah, (Kediri: Darul Mubtadi'in, 2005), 78.

12 Abu Hasim Mubarok, Pintar Nahwu Al-Ajurumiyyah, (Jawa Barat: Mu'jizat 2018), 284

13 Al-Hajj Musthofa Muhammad Nuri, al-'Arabiyah al-Muyassaroh, (Ujung Pandang: Berkah Utami, 1999), 36.

${ }_{14}$ Al-Imrithy, Syaikh Syarifuddin Yahya. Nadzom Imrithy ala matani Al Jurumiyah. (Rembang: Ma'had Ad Dini al anwar Sarang Rembang. 2018), 24
} 
kan oleh amil ibtida, dan khobar di-marfu-kan oleh mubtada. Amil dalam mubtada' bersifat maknawi, yaitu keadaan isim bebas dari amil-amil lafzhiyyah selain zaidah dan hal-hal yang serupa dengannya ${ }^{15}$. Yang dikecualikan selain dari zaidah ialah seperti yang terdapat pada comtoh بحسبك درهم Lafaz Laبك adalah mubtada' yang bebas dari awamil lafzhiyyah selain zaidah, tetapi tidak bebas dari zaidah karena huruf $b a^{\prime}$ yang memasukinya adalah harf zaidah.

Sedangkan 'amil dan khabar bersifat lafzhi, yaitu mubtada. Hal tersebut sesuai dengan mazhab Imam Sibawaih. Akan tetapi, beberapa ahli nahwu berpendapat bahwa 'amil yang beramal dalam mubtada' dan khabar adalah 'amil ibtida'. Dengan demikian maka 'amil pada keduanya bersifat maknawi. Ulama Kufah berpendapat bahwa mubtada khobar itu saling merofa'kan. Mubtada merofa'kan khobar, dan khobar merofa'kan mubtada karena keduanya saling membutuhkan, maka masing-masing manjadi 'amil bagi yang lainnya, seperti ayyan assyarthiyyah menjadi 'amil dalam fi'il sesudahnya, dan f'il itu menjadi 'amil dalam

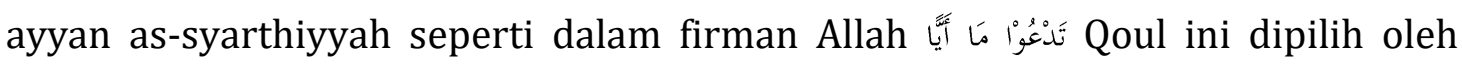
Imam Jalaluddin As-Suyuthi sehingga beliau berkata dalam Alfiyahnya: ومن يقل ترافعا صوبه

Karena 'amil ma'nawi ibtida itu merofa'kan mubtada, maka wajib merofa'kan khobar, Seperti fi'il ketika beramal dalam fa'il, maka beramal (juga) dalam maf'ul bih. ${ }^{16}$ Sebagian ulama berpendapat bahwa khobar itu dirofa'kan oleh amil ma'nawi ibtida, sedangkan khobar dirofa'kan oleh 'amil ma'nawi ibtida bersama mubtada, karena 'amil ma'nawi ibtida itu 'amil yang lemah maka akan kuat dengan (bersama) mubtada seperti kuatnya huruf syarat dengan fi'ilnya ketika beramal bersama-sama dalam fi'il jawab/jaza. ${ }^{17}$

Menurut Ibnu Aqil, yang paling adil adalah pendapat Imam Sibawaih dan Jumhur Ulama Bashroh, bahwa mubtada itu dirofa'kan oleh 'amil ma'nawi ibtida, sedangkan khobar dirofa'kan oleh mubtada. ${ }^{18}$ Mubtada' adalah kalimah isim yang terbaca rofa' yang sunyi dari 'amil lafzhiy kecuali dari amil lafzhiy yang berupa zaidah (tambahan). Contoh : زيد قائم (zaid orang yang berdiri). Amil lafdhi adalah

15 Ibn Malik Al-Andalusi. Alfiyyah Ibn Malik, (Rembang: Maktabah Anwariyah, 2000), 40

16. Muhammad bin Muhammad, Al-Jurumiyah, 26

17 Ibid, 26

18 Bahaudin bin 'Aqil. Syarh Ibn 'Aqil. Surabaya: Al-Haromain, 2003), 31 
amil yang bisa dilihat dan dibaca, seperti 'amil كانdan akhowatnya (saudaranya dan akhowatnya (saudaranya). ظّ dan akhowatnya (saudaranya), kalimah fi'illainnya, huruf jer dan lain-lain. Lafadh كان adalah 'amil lafzhiy, sebab bisa dilihat dan dibaca, ia beramal merofa'kan isim yang asalnya mubtada' dan menasobkan Khobar yang asalnya khobarnya mubtada'. ${ }^{19}$ Lafadh إن adalah 'amil lafzhiy, sebab bisa dilihat dan dibaca ia beramal menasobkan isim yang asalnya mubtada' dan merofa'kan Khobar yang asalnya Khobar mubtada'.20

\section{2) Khobar dan Ruang Lingkup Pembagiannya}

Khobar adalah kata benda yang dibaca rofa' yang secara kalimat disandarkan pada mubtada'. Dalam pengertian lain khobar adalah kalimah isim yang terbaca rofa', menjadi musnad (hukum yang disandarkan pada mubtada'), arti lain dari khobar yaitu juz penyempurna mubtada'.21 Sementara Ibnu Malik mendefinisikan khobar sebagai bagian yang melengkapi faedah. Fa'il dapat dikategorikan ke dalam hal ini. Pendapat lain mengatakan, khabar adalah bagian yang menyatu dalam satu jumlah dengan mubtada', dan fa'il tidak termasuk ke dalam kategori ini karena fa'il bukan merupakan bagian yang satu tatanan dengan mubtada' dalam satu jumlah.

Khobar terbagia menjadi dua yaitu khobar mufrod (khobar yang bukan berupa jumlah/kalimat dan syibh al-jumlah walaupun berbentuk tatsniyah (dual) atau jamak (plural). Kedua adalah khobar ghoiru mufrod. Khobar ghoiru mufrod ini زيد قام : terdiri dari empat macam 1). Fi'il beserta fa'ilnya (jumlah fi'liyah) Contoh زيد جاريته ذاهبة : 2) Mubtada' beserta khobarnya (jumlah ismiyah) Contoha perempuan Zaid pergi). 3) Khobar jar majrur. Contoh : زيد في الدار (zaid di dalam rumah). 4) Khobar zhorof .Contoh : زيد عندك (zaid di sampingmu).

Khobar yang berupa jumlah ismiyah dan fi'liyah diistilahkan dengan khobar jumlah, sedangkan khobar yang berupa jar majrur dan dzorof diistilahkan dengan nama khobar syibh jumlah (menyerupai jumlah), sebab keberadaan jar majrur

19 Muhammad Ma'shum bin Salim Al-Samarani, "Tasywiq Al-Khillan Hasyiyah 'Ala AlJurrumiyyah", (Surabaya: Al-Haramain, tt), 145

20 Abu Hasim Mubarok, Pintar Nahwu Al-Ajurumiyyah, 285.

21 Ibid, 295-296. 
dan dzorof secara kaidah bisa berposisi menjadi sifat, hal, dan sebagai silah maushul, sebagaimana keberadaan jumlah ismiyah.

\section{3) Kaidah-Kaidah Mubtada' dan Khobar (Kaifiatul Ikhbar)}

Setidaknya ada tiga kaidah dalam bentuk kalimat kaifiyatul ikhbar. Pertama adalah Kaidah Mubtada', yang kedua adalah kaidah khobar dan yang ketiga adalah kaidah penerapan kaifiyatul ikhbar.

\section{a) Kaidah Mubtada'}

Setidaknya beberapa kaidah berikut perlu diperhatikan dalam menyusun kalimat dengan susunan yang diawali oleh mubtada'. Pertama mubtada' wajib dibaca rofa' baik secara lafzhiy, taqdiri, atau mahal seperti mubtada' yang dijarkan oleh harf min dan $b a^{\prime}$ yang keduanya dilakukan sebagai zaidah. Contoh: هل من خالق غير الله يرزقكم ربكسبك الله. Lafadh خالق ditarkib menjadi mubtada' dibaca jar secara lafadh, akan tetapi dibaca rofa' secara mahal.

Kedua, boleh membuang mubtada' jika memang terdapat indikasi yang menunjukkan bolehnya tidak menampilkan mubtada', seperti mubtada' berupa isim istifham. Contoh : كيف خالد ؟ (bagaimana khabarnya kholid?) Jawab : مجتهد أي هو مجتهد (dia rajin). Ketiga, hukum asal penyusunan mubtada' adalah mendahului khobar, tidak menutup kemungkinan mubtada' berada di akhir dari khobar. Contoh : عندى زيد (di sampingku ada zaed).

Keempat wajib membuang mubtada'. Dalam hal ini berada pada empat kondisi. Pertama, apabila keberadaan mubtada' yang dibuang diketahui dari jawab qosam (konstruksi sumpah dalam bahasa Arab). Contoh : في ذمتى لأفعلنّ كذا اى في ذمتى عهد أو ميثاق (dalam tanggunganku terdapat janji, sungguh aku akan melakukan hal itu). Kedua, mubtada' yang khobarnya 
ditakhsis (dispesifikkan) oleh lafadz نعم (pujian) atau بئس (cacian). Contoh : نعم الرجل أبو طالب أى هو أبو طالب (sebaik-baik lelaki adalah Abu Tholib) بئس الرجل ابو لهب أى هو أبو لب (sejelek jelek lelaki adalah Abu Lahab).

Ketiga, mubtada' yang khobarnya berkedudukan sebagai pengganti fi'il (kata kerja). Contoh : صبر جميل اى صبرى صبر جميل (kesabaranku adalah kesabaran yang baik). Keempat, mubtada' dan khobar yang asalnya menjadi na'at (sifat). Contoh : أحسن الى ولدك المسكين هو المسكين (berbuat baiklah pada anakmu, yang mana dia miskin).

Mubtada' harus berupa isim ma'rifat (kata benda khusus) dan tidak boleh dibentuk dari isim nakiroh (kata benda umum), ${ }^{22}$ kecuali ada musawwigh (kondisi yang memperbolehkan mubtada' berupa isim nakiroh). Berikut adalah musawwigh (kondisi yang memperbolehkan mubtada' tersusun dari isim nakiroh):

1. Mubtada' berupa isim nakiroh yang dimudlofkan secara lafadh atau makna. Contoh: خخس صلوات كتبهنّ الله (lima shalat diwajibkan oleh Allah SWT), كّل يموت أى كلّ أحد (setiap yang bernyawa akan mati).

2. Mubtada' berupa isim nakiroh yang disifati secara lafdhi, taqdiri (diperkirakan) atau makna seperti lafadh tashghir, hal tersebut لعبد مؤمن خير : dikarenakan tashghir mengandung makna sifat. Contoh Sungguh budak yang beriman lebih baik daripada orang musyrik), أمر أتى بك أى أمر عظيم (masalah besar telah datang padamu).

22. Syaikh Mustafa al-Ghalayani, Jami' Durus Al-Arabiyah, (Cairo: Mathba'ah Univ al-Azhar, 2017), 318. 
3. Mubtada' berupa isim nakiroh yang khobarnya berupa zhorof atau jar majrur yang mendahuluinya. Contoh : وفوق كل ذي علم عليم (di atas setiap orang alim pasti ada yang alim).

Mubtada' berupa isim nakiroh yang jatuh setelah Nafi, istifham, لو لا atau ما أحد عندنا : Contoh إذا الفجائية (Tidak ada satupun orang di sampingku),

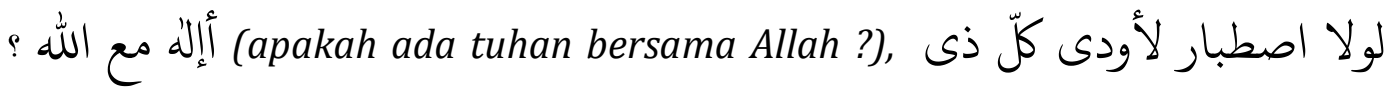
مقة (jika tidak ada kesabaran, maka sungguh ia akan menghalangi setiap sesuatu yang dicinta) خرجت فإذا أسد أماحى) (aku keluar, tiba-tiba macan di depanku)

4. Mubtada' berupa isim nakiroh yang berfungsi sebagai mubtada' pada lafadh setelahnya. Contoh : إعطاء قرشا فى سبيل الله ينهض بالأمة (memberi satu qirsy uang pada jalan Allah, itu dapat membangkitkan ummat).

5. Mubtada' berupa isim mubham (kata benda yang samar maknanya) seperti isim syarat, isim istifham, ma ta'ajjubiyah مال) التّعجبيّة atau kam al-khobariah من كم الخبريّة Contoh: من بيجهد يفلح (orang yang rajin itu akan beruntung), من بجتهد (siapa orang yang rajin?), ما أحسن زيدا (alangkah gantengnya zaed), كم درهم لك (berapa dirham yang engkau miliki?).

6. Mubtada' berupa isim nakiroh yang secara kalimat berfaidah do'a baik atau buruk. Contoh: سلام عليك (semoga keselamatan berpihak 
padamu), ويل للمطففين (semoga cilaka bagi orang yang mengurangi takaran).

7. Mubtada' berupa isim nakiroh yang mengganti kedudukan mausuf (kata yang disifati). Contoh: عالم خير من جاهل أى رجل عالم (laki-laki yang alim lebih baik dariapada yang bodoh).

8. Mubtada' berupa isim nakiroh yang disambung paralel kalimat oleh isim ma'rifat (kata benda khusus). Contoh : رجل وخالد يتعلمان البيان (laki-laki dan kholid belajar ilmu bayan).

9. Mubtada' berupa isim nakiroh yang dikehendaki arti hakikatnya. Contoh : رجل أقوى من امرأة (hakikat laki-laki lebih perkasa dibanding perempuan).

10. Mubtada' berupa isim nakiroh yang menjadi jawab dari pertanyaan. Contoh : رجل عندى (laki-laki di sampingku), من عندك ؟ (siapa disampingmu ?) $)^{23}$

\section{b) Kaidah Khobar}

Adapun khobarnya mubtada' memiliki tujuh kaidah hukum dalam tata sintaksis bahasa Arab. Ketujuh kaidah hukum tersebut diantaranya yaitu:

1. Khobar wajib dibaca rofa' secara lafdz, taqdiri atau mahal seperti khobar berupa jumlah atau syibh jumlah (yang telah dijelaskan di atas).

2. Hukum asal penyusunan kalimat khobar adalah berupa isim nakiroh, dan musytaq (kata benda yang tercetak dari mashdar).

3. Keberadaan khobar harus sesuai dengan mubtada' dalam hal mufrod (tunggal), tasniyah (dual), jama' (plural), mudzakkar (berjenis lakilaki) dan muannats (berjenis perempuan).

${ }^{23}$ Abu Hasim Mubarok, Pintar Nahwu Al-Ajurumiyyah, 289-294. 
4. Boleh tidak menampilkan khobar dalam kalimat apabila ada alasan yang dapat menunjukkan keberadaan khobar yang tidak ditampilkan tersebut. Seperti khobar menjadi jawab Istifham (pertanyaan).

5. Boleh menyusun khobar berbilangan/banyak, seperti khobar yang tersusun dari kata sifat, hal tersebut mengingat sesuatu boleh disifati dengan beberapa sifat.

6. Hukum asal khobar yaitu berada di akhir (diletakkan setelah mubtada').

7. Wajib membuang khobar jika khobar tersebut berada pada empat kondisi berikut:

a) Ketika khobar menunjukkan ma'na umum

b) Khobarnya mubtada' yang disusun untuk menunjukkan kalimat sumpah dalam bahasa Arab.

c) Khobar jatuh setelah huruf waw yang bermakna ma'iyyah (bersamaan)

d) Ketika mubtada' berupa mashdar (kata kerja yang dibendakan), atau isim tafdhil (kata yang menunjukkan makna lebih) yang diidlofahkan pada mashdar, dan setelahnya terdapat hal (keterangan penjelas) yang menempati posisi khobar, akan tetapi tidak layak menjadi khobar.

\section{c) Kaidah kaifiyatul ikhbar}

Dalam konteks penyusun kalimat berbahasa Arab, kaidah kaifiatul ikhbar termasuk pada kaidah yang bersifat dasar dan pondasi. Kaidah kaifiatul ikhbar ini terbentuk dari susunan mubtada dan khobar dan digunakan dalam berbagai bentuk kalimat, termasuk dalam susunan kalimat ijab Kabul pernikahan. Ketepatan pengucapan kalimat ijab Kabul pernikahan termasuk di dalamnya susunan mubtada dan khobarnya menjadi penting mengingat ijab Kabul ini akan menjadi syarat sah atau batalnya sebuah akad pernikahan

Adapun objek material kalimat kaifiatul ikhbar yang akan dibahas di sini adalah lafadz kabul dalam pernikahan yaitu : قبلت نكاحها وتزويجها بالمهر المذكور. 
Dalam kitab taqrirot jurumiyah karya Syeikh Imam Al-Sonhaji ada 11 bentuk kaifiyatul ikhbar dalam akad tersebut sebagaimana dijelaskan dalam point-point berikut:

1) Khobar Musytaq min ism al-Fa'il (خبر مشتق من اسم الفاعل)

Contoh dari Khobar Musytaq min ism al-Fa'i l adalah seperti lafadz berikut: أنا قابل نكاحها وتزويجها بالمهر المذكور. Analisis sintaksis dari lafadz tersebut adalah sebagai berikut: $F a^{\prime} i l$ dalam kalimat qabul di atas dijadikan sebagai mubtada', kemudian fi'ilnya dijadikan sebagai isim fa'il dan dijadikan khobar yang merofa'kan dlomir yang kembali pada mubtada', maka isim fa'il tersebut harus sama dengan mubtada' pada mufrod, tatsniyah, jama', dan mudzakkar muannasnya, adapun maf'ul bih dan jar majrur dalam kalimat qabul di atas tetap, alias tidak berubah.

2) Khobar Musytaq min ism al-Maf'ul (خبر مشتق من اسم المفعول)

Adapun contohnya adalah: نكاحها وتزويجها مقبول بالمهر المذكور. Analisis sintaksis dari lafadz tersebut adalah sebagai berikut: Maf'ul bih dalam akad tersebut dijadikan mubtada', sementara fa'ilnya dibuang kemudian fi'ilnya dijadikan isim maf'ul dan dijadikan khobar yang merofa'kan dlomir yang kembali pada mubtada', maka harus sama dengan mubtada' pada aspek mufrod, tasniyah, jama' dan mudzakkar muannasnya, adapun jar majrur tetap dan tidak berubah.

3) Khobar Jamid min al-Fa'il (خبر جامد من الفاعل)

Adapun lafadznya sebagai berikut: القابل نكاحها وتزويجها بالمهر

المذكور أنا Iijadikan mubtada' dijan disesuaikan dengan khobar dalam mufrod, tatsniyah, jama' dan 
mudzakkar muanntasnya dan fa'il dijadikan khobar diletakkan terakhir. Adapun maf'ul bih dan jar majrur tetap dan tidak berubah.

4) Khobar Jamid min al-Fa'il (خبر جامد من المفعول)

Adapun lafadznya sebagai berikut: المقبول بالمهر المذكور نكاحها

Fi'il dijadikan isim maf'ul diberi ال وتزوبيجها dijadikan mubtada', dan disesuaikan dengan khobar dalam mufrod, tatsniyah, jama', mudzakkar dan muannasnya, dan maf'ul dijadikan khobar diletakkan paling akhir, adapun jar majrur tetap dan tidak berubah.

5) Khobar Jumlah Madliyah 'an al-fa'il ( خبر جملة فعلية ماضية عن (الفاعل

Adapun lafadznya sebagai berikut: أنا قبل نكاحها وتزويجها

Fa'il dijadikan mubtada', fi'il madli mabni fa'il dijadikan khobar dan diberi dlomir yang kembali pada mubtada', adapun maf'ul bih dan jar majrur tetap dan tidak berubah.

6) Khobar Jumlah Madliyah 'an al-Maf'ul C خبر جملة فعلية ماضية عن )

Adapun lafadznya sebagai berikut: نكاحها وتزويجها قبل بالمهر المذكور Maf'ul bih dijadikan mubtada', fa'il dibuang, fi'il madli dimabnikan majhul dijadikan khobar, dan diberi dlomir yang kembali pada mubtada', adapun jar majrur tetap dan tidak berubah. 
7) Khobar Jumlah Fi'liyah Mudloro'iyah 'an al-fa'il ( خبر جملة فعلية (مضارعية عن الفاعل

Adapun lafadznya sebagai berikut: أنا أقبل نكاحها وتزويجها Fa'il dijadikan mubtada', fi'il mudlori' mabni fa'il dijadikan khobar dan diberi dlomir yang kembali pada mubtada', adapun maf'ul bih dan jar majrur tetap dan tidak berubah.

8) Khobar Jumlah Fi'liyah Mudloro'iyah ‘an al-Maf'ul ( خبر جملة فعلية (مضارعية عن المفعول

Adapun lafadznya sebagai berikut:

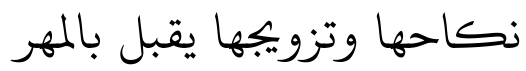

المذكور Maf'ul bih dijadikan mubtada', fa'il dibuang, fi'il mudlori' dimabnikan majhul dijadikan khobar dan diberi dlomir yang kembali pada mubtada', adapun jar majrur tetap dan tidak berubah.

9) Khobar Jumlah Ismiyah bismi al-Fa'il Jara 'ala man Huwa Lahu إسمية باسم الفاعل جرى على من هو له ) (جملة Adapun lafadznya sebagai berikut: نكاحها وتزويجها أنا قابله Maf'ul bih dijadikan mubtada' pertama, fa'il dijadikan mubtada' kedua, kemudian fi'il dijadikan isim fa'il dan dijadikan khobarnya mubtada' kedua dan merofa'kan dlomir yang kembali pada mubtada' kedua, maka isim fa'il tersebut harus sesuai dengan mubtada' kedua dalam mufrod, tasniyah, jama', mudzakkar dan muannatsnya, kemudian dimudlofkan kepada dlomir yang kembali pada mubtada' pertama, adapun jar majrur tetap dan tidak berubah, kemudian 
jumlahnya mubtada' kedua dan khobarnya menjadi khobarnya mubtada' pertama.

10)Khobar Jumlah Ismiyah Bismi al-Fail 'ala Ghair Man Huwa Lahu

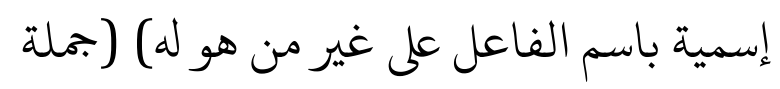

Adapun lafadznya sebagai berikut: أنا نكاحها وتزويجها قابله هو

Fa'il dijadikan mubtada' pertama, maf'ul dijadikan mubtada' kedua, kemudian fi'il dijadikan isim fa'il dan dijadikan khobarnya mubtada' kedua, dan dimudlofkan kepada dlomir yang kembali pada mubtada' kedua, kemudian dlomir munfasil yang kembali pada mubtada' pertama dirofa'kan oleh isim fa'il tersebut, maka isim fa'il tersebut harus tetap mufrod dan sesuai dengan mubtada' pertama dalam mudzakkar dan muannatsnya. Adapun jar majrur tetap dan tidak berubah.

11) Khobar Syibh Jumlah (خبر شبه جملة)

Adapun lafadznya sebagai berikut: قبولي نكاحها وتزويكها بالمهر

. Fi'il dijadikan masdar, dimudlofkan pada fa'il atau maf'ul bih dan dijadikan mubtada', kemudian jar majrur dijadikan khobar, hal tersebut jika mudlof pada fa'il maf'ul bihnya tetap, dan jika mudlof pada maf'ul bih fa'il dibuang contohnya seperti berikut: ضَرْبُ زيدٍ عمرا في الدارِ زيدُ في الدار ضَرْبُ عمرٍ في الدارِ ضرب عمرٍ

\section{d) Pengecualian}

Para ulama fikih sepakat bahwa syarat ucapan ijab-kabul harus dengan lafal fi'il madhi yang menunjukkan kata kerja telah lalu, atau salah satunya fi'il madhi dan yang lain fi'il mustaqbal yang menunjukkan kata kerja yang 
sedang berlangsung. Contoh ijab-kabul yang menggunakan fi'il madhi tersebut adalah sebagai berikut:

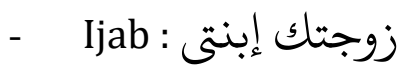

"saya nikahkan engkau kepada anak perempuan saya”

Kabul : قبلت "saya terima”

Contoh ijab-kabul yang salah satunya fi'il madhi dan lainnya fi'il mustaqbal :

- Ijab : أزوجك إبنتى"sekarang saya nikahkan engkau dengan kepada anak perempuan saya".

- Kabul : قبلت "saya terima”

Mereka mensyaratkan hal tersebut karena keridaan dan kerelaan kedua belah pihak merupakan hal yang pokok dalam akad nikah. Dengan demikian, bisa diketahui dengan jelas, dan karena ijab kabul merupakan lambang keeridaan kedua belah pihak, maka harus diucapkan dengan lafal yang pasti menunjukkan keridaan dan secara konkret dinyatakan dengan tegas pada saat akad nikah berlangsung.

Bentuk ucapan dalam ijab kabul yang dipergunakan oleh agama adalah fi'il madhi, karena menyatakan secara tegas lahirnya pernyataan setuju dari kedua belah pihak dan tidak mungkin mengandung arti yang lain. Berbeda dengan ucapan yang dinyatakan dengan fi'il mustaqbal yang tidak secara tegas menunjukkan adanya keridaan ketika dinyatakan.

Andaikata salah seorang dari mereka berkata :

"sekarang saya nikahkan anak perempuan saya kepada kamu" lalu penerima menjawab أقبل "saya terima sekarang". Ucapan kedua belah pihak ini tidak secara tegas menyatakan telah terjadinya akad nikah dengan sah, karena masih ada kemungkinan bahwa yang dimaksudkan hanya merupakan suatu perjanjian semata. Sedangkan 
perjanjian untuk pernikahan di masa mendatang bukan berarti telah terjadi ikatan pernikahan pada saat sekarang.

Andaikata peminang berkata kawinkanlah putri bapak kepada saya." Lalu walinya menjawab : زوجتها لك "ya saya kawinkan dia dengan kamu", berarti telah terjadi akad nikah, karena ucapan tersebut telah menunjukkan adanya pernyataan memberikan kuasa akad nikah sekaligus, padahal akad nikah itu sah dilakukan dengan menguasakan kepada salah satu pihak untuk melaksanakannya.

Jika peminang mengatakan "kawinkanlah putri bapak dengan saya". Lalu walinya menjawab, "saya terima". Dengan demikian, berarti pihak pertama menguasakan kepada pihak kedua, lalu pihak kedua mengadakan akad nikah sesuai dengan permintaan pihak pertama.

Selanjutnya, menyikapi tanggapan masyarakat khususnya di Indonesia mengenai pertanyaan seperti "Bagaimana jika kaifiyatul ikhbar qobul tersebut diucapkan oleh wali nikah serta calon suami tetapi dengan menggunakan lafadz bahasa Indonesia yang bisa jadi menyalahi akad yang telah ditetapkan oleh para fuqoha? "misalnya lafadz qobiltu itu seharusnya jika diterjemahkan ke bahasa Indonesia jadi "telah saya terima" tetapi yang terjadi di masyarakat akad nikah biasanya menggunakan kata "saya terima" saja, telahnya menjadi hilang. Apakah sah?

Jawabannya menurut pendapat para ulama khususnya di Indonesia, mengenai hal tersebut merupakan hal yang maklum dan bisa dikatakan sah saja. Karena lafadz qobiltu itu pada dasarnya berasal dari bahasa Arab, sedangkan lafadz "saya telah terima nikah dan kawinnya" itu dari bahasa Indonesia. Maka pengucapan lafadz "telah" tersebut khusunya di Indonesia tidaklah menjadi suatu keharusan, karena sudah pasti kejelasannya. Sehingga dianggap suatu hal yang maklum tanpa harus menyebutkan lafadz "telah", selain itu alasannya adalah untuk mempersingkat kata dikarenakan lafadz "telah" sudah jelas sehingga tidak perlu di ucapkan layaknya terjemahan dari lafadz "qobiltu nikahaha" dalam bahasa Arab. 


\section{KESIMPULAN}

Dalam konstruksi sintaksis kaifiyatul ikhbar yang terdapa pada akad ijab Kabul pernikahan setidaknya terdapat 11 bentuk kaifiyatul ikhbar dengan spesifikasi analisis sintaksisnya yang beragam. Hal tersebut menunjukkan bahwa bentuk kaifiatul ikhbar dalam akad ijab kabul pernikahan sebenarnya tidak hanya tunggal sebagaimana yang diketahui secara luas oleh masyarakat, akan memiliki bentuk konstruksi kalimat yang beragam. Akan tetapi beragamnya kaidah ucapan kaifiyatul ikhbar ijab Kabul tersebut belum sepenuhnya diketahui secara luas. Para ulama fikih telah bersepakat bahwa syarat ucapan ijab kabul dalam pernikahan harus dengan menggunakan lafadz fi'il madhi yang menunjukkan kata kerja telah lampau, atau salah satunya fi'il madhi dan yang lain fi'il mustaqbal yang menunjukkan kata kerja yang sedang berlangsung.

Adapun kaidah ijab Kabul dalam pernikahan yang sering dilafadzkan oleh masyarakat umumnya menggunakan kata "saya terima" dan tidak menggunakan kata "telah saya terima" sebagaimana keharusan penggunaan fiil madly sebagaimana konstruksi sintaksis bahasa Arab yang seharusnya. Para ulama khususnya di Indonesia berpandangan bahwasannya pengucapan tersebut adalah hal yang maklum dan bisa dikatakan sah saja. Karena lafadz qobiltu itu pada dasarnya berasal dari bahasa Arab, sedangkan lafadz "saya telah terima nikah dan kawinnya" itu dari bahasa Indonesia. Maka pengucapan lafadz "telah" tersebut khusunya di Indonesia tidaklah menjadi suatu keharusan, karena sudah pasti kejelasannya.

\section{DAFTAR PUSTAKA}

Al ghalayin, Mustofa bin Muhammad bin Salim. (2017). Jami'ud Durus al Arobiyyahh. Daruuttaqwa. Al Azhar kairo.

Al-Andalusi, Ibn Malik. (2000). Alfiyyah Ibn Malik. Rembang: Maktabah Anwariyah.

Al-Imrithy, Syaikh Syarifuddin Yahya. 2018. Nadzom Imrithy ala matani Al Jurumiyah. Rembang: Ma'had Ad Dini al anwar Sarang Rembang.

Al-Samarani, Muhammad Ma'shum bin Salim. Tt. "Tasywiq Al-Khillan Hasyiyah 'Ala AlJurrumiyyah". Surabaya: Al-Haramain.

'Aqil, Bahaudin bin. (2003). Syarh Ibn 'Aqil. Surabaya: Al-Haromain 
Asy'ari, Hasyim. (2017). Nadzariyatu Nasy'ati al-Lughoh wa tafri'uha fi at-Thurab alArabiy. at-Tadris. al-Mujallad as-Saniy.

Blaxter, Loraine. Christina Hughes, Malcolm Thight. 2001. How To Research. England: Open University Press.

Huda, Muhammad Muchlish. (2018). al-Paidagogiyatu an-naqdiyyatu: al-Ittijah aljadid fi ta'lim al-lughah al-arabiyah li ghair an-nathiqina biha. Abjadia International Journal of Education, Vol 3 No. 1. http://ejournal.uinmalang.ac.id/index.php/abjadia/article/view/5993

Mubarok, Abu Hasim. 2018. Pintar Nahwu Al-Ajurumiyyah, Bandung: Mu'jizat

Muhammad, Muhammad bin. 2005. Al-Jurumiyah. Kediri: Darul Mubtadi'in.

Nasution, S. (1988). Metode Penelitian Naturalistik Kualitatif. Bandung: Tarsito.

Ni'mah, Fuad. TT. Mulakhkhash Qawaid al-Lughah al-Arabiyah. Beirut: Dar alTsaqafah al-Islamiyah.

Nuri, al-Hajj Musthofa Muhammad. (1999). al-'Arabiyah al-Muyassaroh. Ujung Pandang: Berkah Utami.

Shiddiq, Jamaluddin. “Model Pembelajaran Bahasa Arab Di Ma'had Al-Jami'ah Walisongo Semarang." Lisania: Journal of Arabic Education and Literature 2, no. 2 (2018): 102-20.

Yin, Robert K. (2009). Studi Kasus: Desain dan Metode. Terj. M. Djauzi Mudzakir. Jakarta: Rajawali Pers. 